\title{
Primocane-fruiting Raspberry Production in High Tunnels in a Cold Region of the Upper Midwestern United States
}

\author{
Shengrui $\mathrm{YaO}^{1,3}$ and Carl J. Rosen ${ }^{2}$
}

ADDITIONAL INDEX WORDs. Rubus idaeus, season extension, winter survival

SUMMARY. Five primocane raspberry ( $R$ ubus $i d a e u s)$ cultivars were evaluated in a high tunnel and in the field at Grand Rapids, MN, which is located in U.S. Department of Agriculture (USDA) plant hardiness zone 3b. Bare root plants of five cultivars (Autumn Bliss, Autumn Britten, Caroline, Joan J, and Polana) were planted in the high tunnel and in the field, each with a randomized complete block design at $2 \times 5.2$ - $\mathrm{ft}$ spacing on 8 May and 14 May 2008, respectively. A propane heater was used periodically for frost protection in the high tunnel. All five cultivars overwintered well and primocanes emerged with minor or no winter damage in the high tunnel in 2009. The high tunnel extended the growing season for $\approx 4$ weeks in both years. Raspberry plants in the high tunnel produced higher yield than those in the field, total $154 \mathrm{lb}(6655 \mathrm{lb} / \mathrm{acre})$ from the high tunnel vs. $0.5 \mathrm{lb}(43 \mathrm{lb} / \mathrm{acre})$ from the field in 2008 and $379 \mathrm{lb}(16,378 \mathrm{lb} / \mathrm{acre})$ vs. $80 \mathrm{lb}(3457 \mathrm{lb} / \mathrm{acre})$ in 2009. 'Caroline' and 'Polana' had higher yields than 'Autumn Bliss'; 'Joan J' and 'Autumn Britten' yields were intermediate and not different from 'Caroline', 'Polana', or 'Autumn Bliss' yields. In terms of harvest date, 'Polana' was the earliest among the five cultivars tested, followed by 'Autumn Britten', 'Autumn Bliss', and 'Joan J'. 'Caroline' was the latest. Essential nutrients in leaves for all cultivars both in the field and in the high tunnel were within sufficient ranges. Spider mites (Tetranychidae) and raspberry sawflies (Monophanoides geniculatus) were the major insect problems. In conclusion, primocane-fruiting raspberries can be successfully grown in high tunnels and produce substantially higher yields than in field plantations in northern Minnesota or areas with similar climatic conditions.

$\mathrm{N}$ orthern Minnesota is typical of many high-latitude and high-elevation areas of the United States in having cold winters and short, cool growing seasons. In the north central region of Minnesota, the Grand Rapids area averaged a growing season of $115 \mathrm{~d}$ from 1916 to 2009 and is classified as the USDA plant hardiness zone $3 \mathrm{~b}$ (Cathy, 1990; National Weather Service, 2006). The harsh weather combined with the short growing season significantly

The authors thank Jim Luby at University of Minnesota and Steve Guldan at New Mexico State University for their critical review of this manuscript before submission. The authors acknowledge Editor-in-Chief Neal De Vos, Consulting Editor Joan Davenport, and three anonymous reviewers for their constructive comments to the previous version of this manuscript. The experiment was conducted at North Central Research and Outreach Center (NCROC), University of Minnesota at Grand Rapids, MN. The authors thank Pat Johnson and Keith Mann at NCROC for their technical support and acknowledge the support from the Northeast Minnesota Sustainable Development Partnership Program.

${ }^{1}$ Department of Plant and Environment Sciences, Sustainable Agriculture Science Center at Alcalde,

New Mexico State University, Alcalde, NM 87511

${ }^{2}$ Department of Soil, Water and Climates, University of Minnesota, St. Paul, MN 55108

${ }^{3}$ Corresponding author. E-mail: yaos@nmsu.edu. increases the risk of freezing before a crop can be harvested for primocane-fruiting raspberries. In warm years with later killing frosts, growers can expect to have a reasonable crop of fall raspberries; but in other years, growers might have a minimal crop or none at all (D. Wildung, personal communication). For these reasons, there is very limited primocane raspberry production in northern Minnesota (USDA, 2009a), although the crop is one of high value.
High tunnels have the potential to extend the growing season by several weeks in the spring and fall, which would be a benefit for fallbearing raspberries (Demchak, 2009; Heidenreich et al., 2009). In high tunnels with an additional 3 to 4 weeks of growing season (Wells and Loy, 1993), the majority of the primocanefruiting raspberry fruit would be harvestable. Fall-bearing raspberries have been successfully grown in high tunnels in New York, Pennsylvania, and other cold-climate states, but the upper midwestern United States presents unique climatic limitations. Tomato (Solanum lycopersicum), pepper (Capsicum annuum), lettuce (Lactuca sativa), and other annual vegetables have been successfully grown in high tunnels at Grand Rapids, MN, since 2003 (Wildung et al., 2007). One of our research goals was to evaluate the potential for perennial crops in high tunnels and primocane-fruiting raspberry is an ideal crop to investigate. This high tunnel primocane raspberry experiment was initiated in 2008. The objectives were to investigate the potential of high tunnel season extension for fall raspberries, compare commercially available cultivars, monitor crop nutrition, pests, and diseases, and assess possible winter damage in a USDA plant hardiness zone $3 \mathrm{~b}$ area.

\section{Materials and methods}

This study was conducted at the North Central Research and Outreach Center, University of Minnesota at Grand Rapids, MN, which is located in USDA plant hardiness zone $3 \mathrm{~b}$ (Cathy, 1990) [lat. $47^{\circ} 14^{\prime} 33.30^{\prime \prime} \mathrm{N}$, long. $93^{\circ} 29^{\prime} 33^{\prime \prime} \mathrm{W}$, elevation $1288 \mathrm{ft}$, average last freeze date 19 May and average first freeze date of 22 Sept.

\begin{tabular}{llll}
\hline $\begin{array}{l}\text { Units } \\
\begin{array}{l}\text { To convert U.S. to SI, } \\
\text { multiply by }\end{array}\end{array}$ & U.S. unit & SI unit & $\begin{array}{l}\text { To convert SI to U.S., } \\
\text { multiply by }\end{array}$ \\
\hline 1.0551 & $\mathrm{Btu}$ & $\mathrm{kJ}$ & 0.9478 \\
1 & $\mathrm{cbar}$ & $\mathrm{kPa}$ & 1 \\
0.3048 & $\mathrm{ft}$ & $\mathrm{m}$ & 3.2808 \\
0.0283 & $\mathrm{ft}^{3}$ & $\mathrm{~m}^{3}$ & 35.3147 \\
3.7854 & $\mathrm{gal}$ & $\mathrm{L}$ & 0.2642 \\
2.54 & inch $(\mathrm{es})$ & $\mathrm{cm}$ & 0.3937 \\
0.4536 & $\mathrm{lb}$ & $\mathrm{kg}$ & 2.2046 \\
1.1209 & $\mathrm{~b} / \mathrm{acre}$ & $\mathrm{kg} \cdot \mathrm{ha}^{-1}$ & 0.8922 \\
1 & $\mathrm{mmho} / \mathrm{cm}$ & $\mathrm{dS} \cdot \mathrm{m}^{-1}$ & 1 \\
28.3495 & $\mathrm{oz}$ & $\mathrm{g}$ & 0.0353 \\
1 & $\mathrm{ppm}$ & $\mathrm{mg} \cdot \mathrm{kg}^{-1}$ & 1 \\
6.8948 & $\mathrm{psi}$ & $\mathrm{kPa}$ & 0.1450 \\
$\left({ }^{\circ} \mathrm{F}-32\right) \div 1.8$ & ${ }^{\circ} \mathrm{F}$ & ${ }^{\circ} \mathrm{C}$ & $\left(1.8 \times{ }^{\circ} \mathrm{C}\right)+32$
\end{tabular}


from 1980 to 2009 (National Weather Service, 2006)].

The soil at this site is Rosy sandy loam (USDA, 2009b). A $21 \times 48$-ft high tunnel and an adjacent identicalsized field plot were set up in a randomized complete block design with four replicates. Bare root plants of five primocane-fruiting raspberry cultivars, Autumn Bliss, Autumn Britten, Caroline, Joan J, and Polana, were planted both in the high tunnel and in the field at $2 \times 5.2$ - $\mathrm{ft}$ spacing on 8 May and 14 May 2008, respectively. A drip irrigation system of two drip tapes per row [12 inch apart emitters, 0.45 $\mathrm{gal} / \mathrm{min}, 27 \mathrm{gal} / \mathrm{h}$ for $100 \mathrm{ft}$ at $8 \mathrm{psi}$ (T-tape; John Deere Water, San Marcos, CA)] was installed, one on each side of the plants in the high tunnel. Water was supplied weekly for $1 \mathrm{~h}$ in the spring after planting in the high tunnel and increased to two to three times per week in midsummer. Watermark soil moisture sensors and a datalogger (Spectrum Technologies, Plainfield, IL) were used to monitor soil moisture and the threshold for irrigation was -25 cbar at the 4 -inch soil depth. One drip tape per row was used for the field planting to complement the rainfall. The irrigation frequency was $1 \mathrm{~h}$ per week to $2-3 \mathrm{~h}$ per week as needed, and this supplemental irrigation ended in early October in the field.

In the first growing season after planting and from mid-March in the second year until September, the sides of the high tunnel were kept open for heat dissipation and ventilation. Beginning in September in both years, when evening temperatures dropped below $40{ }^{\circ} \mathrm{F}$, the sides of the high tunnel were closed at night and a 80,000-Btu propane heater (Scheu Products Co., Rancho Cucamonga, CA) for frost protection was in place with a thermostat set at 34 to $35^{\circ} \mathrm{F}$. In October, the high tunnel was kept closed, except for a ventilation period of 30 to $60 \mathrm{~min}$ per day to allow accumulated moisture to escape. The propane heater was removed from the high tunnel when the harvest season ended. In winter, the high tunnel was kept closed; and on 20 Dec. 2008, snow was shoveled in from nearby fields to cover rows 3 and 4 in the high tunnel while rows 1 and 2 were left uncovered to test the snow cover effect on plant overwintering. Snow cover of roughly $1 \mathrm{ft}$ wide on each side of the plants and $\mathrm{l} \mathrm{ft}$ deep was mounded along the designated rows. For the field planting, the plants were covered with natural snow all winter with no extra snow mulch or removal. The snow in the high tunnel had melted by late Feb. 2009. As temperatures warmed up inside the high tunnel, with maximum air temperature reaching $70{ }^{\circ} \mathrm{F}$ and the soil temperature around 31 to $32{ }^{\circ} \mathrm{F}$, canes from the previous season were pruned to the ground on 12 Mar. 2009 and the sides of the high tunnel were opened.

In mid-May 2009, primocane number of each plot in the high tunnel was counted and 'Caroline' plots and selected plots of 'Joan J' and 'Polana' with high primocane numbers were manually thinned to six to seven primocanes per linear foot. In early July 2009 , in one plot of 'Caroline' that had plants of $7 \mathrm{ft}$ high, primocanes were pinched back several inches to stimulate lateral branches and control height. For the field planting, there was no primocane thinning or pinching. Plant height for all plots (at least three primocanes from each original plant) was measured in both years. At the beginning of the harvest season, fruit was picked weekly and then twice per week or as needed until the end of the season. In 2008, the total fruit number and total weight were recorded for each harvest; in 2009, the average weight of 25 berries and total weight were collected through the season.

In Mar. 2008, soil samples in the field and in the high tunnel were taken at two depths (0-6 inches and 6-12 inches) and analyzed at the University of Minnesota Soil Testing Laboratory using standard procedures (Brown, 1998), and the results are presented in Table 1. According to recommendations based on soil test results (Rosen and Eliason, $2005), 1.5 \mathrm{lb}$ of $20 \mathrm{~N}-4.4 \mathrm{P}-8.3 \mathrm{~K}$ fertilizer [equivalent to $50 \mathrm{lb} /$ acre nitrogen $(\mathrm{N})]$ was incorporated into each of the four $48-\mathrm{ft}$ rows in the tunnel before planting. In addition, one bag of garden compost per $48-\mathrm{ft}$ row ( $1 \mathrm{ft}^{3}$ per bag; Waupaca Materials, Waupaca, WI) was incorporated 6-8 inches deep into each row in the high tunnel before planting to increase soil organic matter content. One bag of compost and $1.5 \mathrm{lb}$ of $20 \mathrm{~N}-4.4 \mathrm{P}-8.3 \mathrm{~K}$ fertilizer per row were also incorporated into each row of the field site before planting. In $2009,0.53 \mathrm{lb} 46 \mathrm{~N}-0 \mathrm{P}-0 \mathrm{~K}$ and 0.67 $\mathrm{lb}$ of $15.5 \mathrm{~N}-0 \mathrm{P}-0 \mathrm{~K}$ fertilizers per row (total equivalent to $60 \mathrm{lb} /$ acre $\mathrm{N}$ ) were applied through fertigation in the high tunnel, while the field planting was side-dressed with $1.39 \mathrm{lb}$ of $20 \mathrm{~N}-4.4 \mathrm{P}-8.3 \mathrm{~K}$ fertilizer per row (60 lb/acre N).

About 40 to 50 of the most recently matured leaves for each plot were collected with petioles removed for nutrient analyses in the high tunnel on 7 Sept. 2008 and 23 July 2009. Samples were dried and then ground to pass through a 20-mesh screen. Multiple elements in dry ashed samples were determined using inductively coupled plasma optical emission spectrometry (model 35601; Applied Research Laboratories, Sunland, CA) (Fassel and Kniseley, 1974; Munter and Grande, 1981). Total nitrogen was determined by the combustion method (Horneck and Miller, 1998) using a Leco analyzer (Leco Corp., St. Joseph, MI). For the field planting, due to missing plants and lack of an adequate number of leaves in the planting year, a combined sample of 40 to 50 leaves from each cultivar was taken for nutrient analyses at the same date with similar procedures as in the high tunnel for both years.

During the blooming period, wild bumble bees (Bombus spp.) and other insects were present for pollination in both the high tunnel and the field. Pest and disease pressures were monitored weekly and treated as necessary. In the high tunnel, parasitic mites (Neoseiulus fallacies) were released to control spider mites (Tetranychidae) in May and July 2009. Air temperatures inside and outside of the high tunnel were recorded, as well as soil temperature in winter using Hobo Pro or Hobo 4-channel dataloggers (Onset Computer, Bourne, MA).

All high tunnel plant growth and yield data were analyzed using analysis of variance with Statistix software (Analytical Software, Tallahassee, FL) and each year was analyzed separately. Due to missing plants, field data were analyzed the same way as high tunnel data, but with only three replicates.

\section{Results and discussion}

WEATHER AND HIGH TUNNEL TEMPERATURES. The weather patterns of 2008 and 2009 were quite different. 


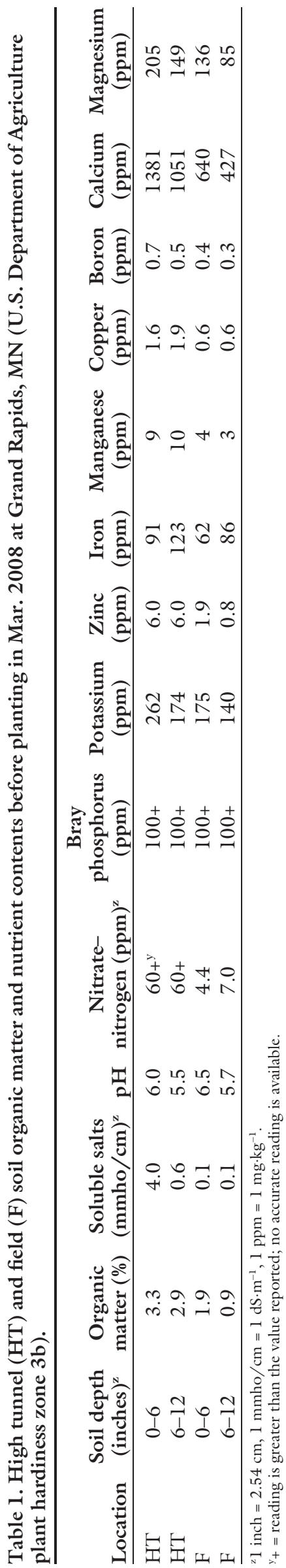

In 2008, the year of establishment, August, September, and October were slightly warmer than the 30 year average (Table 2). In 2009, Grand Rapids, MN, experienced a very cold late spring and early summer as May, June, and July had average temperatures well below the 30 -year average. July was the sixth coldest on record since $1915(\mathrm{Na}-$ tional Weather Service, 2006). With high tunnel sides open, the maximum temperatures rarely reached $90{ }^{\circ} \mathrm{F}$ in July and Aug. 2009. Later in the season, the monthly average temperature of September was the same as in July (Table 2). Sept. 2009 was the hottest September on record since 1915 (National Weather Service, 2006). The warm September temperatures allowed the plants to recover from their setback earlier in

Table 2. Monthly average air temperatures in 2008 and 2009 and 30-year average at Grand Rapids, MN (U.S. Department of Agriculture plant hardiness zone 3b) (National Weather Service, 2006).

\begin{tabular}{lccc}
\hline & $\mathbf{2 0 0 8}$ & 2009 & 30-yr Avg \\
\cline { 2 - 4 } Mo. & \multicolumn{3}{c}{$\left({ }^{\circ} \mathbf{F}\right)^{\mathbf{z}}$} \\
\hline May & 50.2 & 51.4 & 54.4 \\
June & 61.8 & 61.3 & 62.9 \\
July & 66.9 & 62.6 & 67.2 \\
August & 66.4 & 63.1 & 64.9 \\
September & 57.1 & 62.6 & 54.7 \\
October & 45.3 & 38.7 & 43.5 \\
\hline${ }^{2}\left({ }^{\circ} \mathrm{F}-32\right) \div 1.8={ }^{\circ} \mathrm{C}$.
\end{tabular}

the growing season. When frost was predicted in early October, the propane heater kept the temperature above $35{ }^{\circ} \mathrm{F}$ in both years. The supplemental heat at night allowed the plants to keep producing until early November both years.

The high tunnel structure increased maximum/minimum temperatures during the winter. In the winter of 2008-09, minimum air temperatures inside the closed high tunnel were kept above $-20{ }^{\circ} \mathrm{F}$, while the outside temperature reached $-40{ }^{\circ} \mathrm{F}$ on 16 Jan. 2009. From 1 Dec. 2008 to 15 Mar. 2009, the average maximum/minimum air temperatures were $38.0 / 4.0^{\circ} \mathrm{F}$ inside the high tunnel vs. $22.3 /-6.5^{\circ} \mathrm{F}$ outside the high tunnel.

Yield AND haRvest SEASON. Primocane-fruiting raspberries produced well during their planting year in 2008 in the high tunnel. The harvest peaked in October for that year (Fig. 1). Cultivars did not differ significantly, with yields ranging from $1.9 \mathrm{lb} /$ plant for 'Polana' to $1.5 \mathrm{lb} /$ plant for 'Caroline'. In 2009, with the extremely cold July temperatures, the season peaked in late September to early October (Fig. 1). 'Caroline' and 'Polana' had the highest yields and were significantly higher than those of 'Autumn Bliss' (Table 3). 'Joan J' and 'Autumn Britten' yields were intermediate but not significantly different from those of 'Caroline', 'Polana', or 'Autumn Bliss'. 'Caroline' produced the highest yield among the five cultivars tested, but it also had more

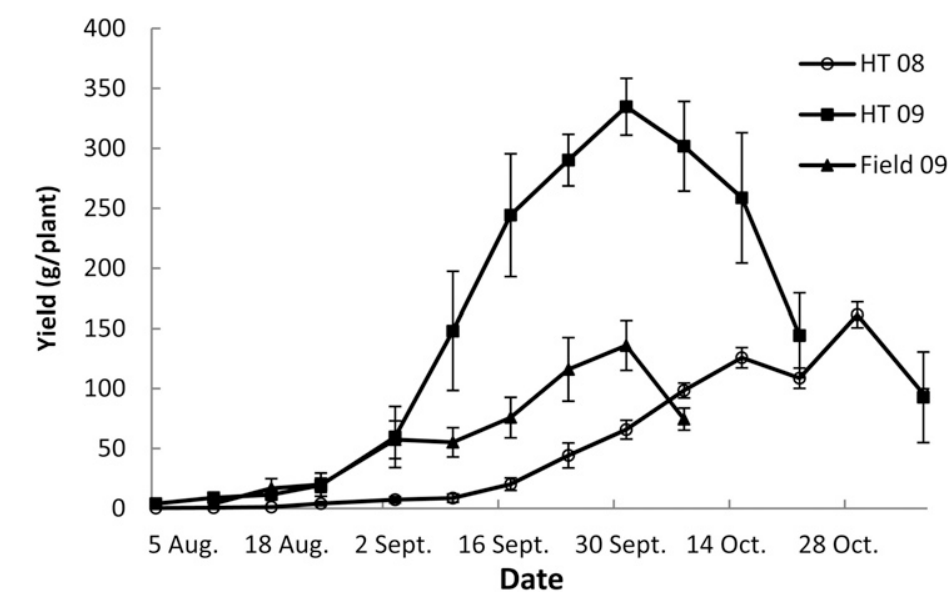

Fig. 1. The average yield of five primocane-fruiting raspberry cultivars in the high tunnel in 2008 (HT 08) and 2009 (HT 09) and in the field in 2009 (Field 09) at Grand Rapids, MN (U.S. Department of Agriculture plant hardiness zone 3b). The error bars denote SE among cultivars; $1 \mathrm{~g}=0.0353 \mathrm{oz}$. 
Table 3. Primocane-fruiting raspberry yield and fruit size both in the high tunnel and in the field for 2008 and 2009 at Grand Rapids, MN (U.S. Department of Agriculture plant hardiness zone 3b). The fruit size data for 2008 represent the average for all the berries picked, and the 2009 data were the average of 25 berries from each harvest. The yield per plant was equivalent weight per original plant in 2008 .

\begin{tabular}{|c|c|c|c|c|c|}
\hline \multirow[b]{3}{*}{ Cultivar } & \multicolumn{3}{|c|}{ High tunnel } & \multicolumn{2}{|c|}{ Field } \\
\hline & \multicolumn{2}{|c|}{ Fruit size $(\mathrm{g})^{\mathrm{z}}$} & \multirow{2}{*}{$\frac{\text { Yield } 2009}{\text { lb/plant }(\mathrm{lb} / \text { acre })^{\mathrm{z}, \mathrm{y}}}$} & \multirow{2}{*}{$\frac{\text { Fruit size }(\mathrm{g})}{2009}$} & \multirow{2}{*}{$\frac{\text { Yield } 2009}{\mathrm{lb} / \text { plant (lb/acre) }}$} \\
\hline & 2008 & 2009 & & & \\
\hline Autumn Britten ${ }^{\mathrm{w}}$ & $5.2 \mathrm{a}$ & $4.2 \mathrm{~b}$ & $3.94(20,446) a b$ & $4.2 \mathrm{a}$ & $1.56(6,534) \mathrm{a}$ \\
\hline Caroline & $4.1 \mathrm{~b}$ & $4.2 \mathrm{~b}$ & $4.98(25,849)$ a & $3.8 \mathrm{~b}$ & $0.96(4,021) \mathrm{a}$ \\
\hline Joan J & $4.9 \mathrm{a}$ & $4.6 \mathrm{a}$ & $4.46(23,564) \mathrm{ab}$ & $4.4 \mathrm{a}$ & $1.13(4,733) \mathrm{a}$ \\
\hline
\end{tabular}

${ }^{\mathrm{z}} \mathrm{l} \mathrm{g}=0.0353 \mathrm{oz}, \mathrm{l} \mathrm{lb}=0.4536 \mathrm{~kg}, \mathrm{l} \mathrm{lb} / \mathrm{acre}=1.1209 \mathrm{~kg} \cdot \mathrm{ha}^{-1}$.

y Calculated average yields (lb/acre) were based on the yield per plant and planting density, which was higher than the actually harvested yield due to the operation space without plants near the doors and at the end of each row. The yields of the field plantings were similar due to missing plants.

${ }^{x}$ Any two means within a column not followed by the same letter are significantly different at $P \leq 0.05$ with Fisher's protected least significant difference procedure.

wThe double berries exaggerated the average berry size for 'Autumn Britten' in 2008.

unpicked fruit because of its late maturity. Most cultivars produced over $90 \%$ to $95 \%$ marketable fruit, except for 'Autumn Bliss' (50\% to $60 \%$ ), which had short, small, and crumbly fruit.

Among the five cultivars tested, 'Polana' was the earliest, followed by 'Autumn Britten', 'Autumn Bliss', and 'Joan J'. 'Caroline' was the latest cultivar, 2 weeks later than 'Polana'. Although harvest season ended 6 Nov. both years, there were still some fruit hanging on the plants, especially on the late cultivar Caroline. But due to the cold and cloudy weather at that time, the fruit matured very slowly and the propane heater stayed on during daytime, which was an indication that the harvest season had ended.

Even with the unusually cool July and warm September in 2009, primocane raspberry plants in the high tunnel grew and produced well with a total of $379 \mathrm{lb}(16,378 \mathrm{lb} /$ acre) of berries for the $21 \times 48$-ft high tunnel. This yield is comparable to yields reported from high tunnel studies in western New York and central Pennsylvania sites with more moderate climates (Demchak, 2009).

For the field planting, a total of $0.5 \mathrm{lb}(43 \mathrm{lb} /$ acre $)$ of berries was harvested from all five cultivars of the whole field planting and the season ended with the first frost $\left(28^{\circ} \mathrm{F}\right)$ on 3 Oct. 2008. This low yield was partially because of the longer establishment period in the first year of the field planting. In 2009, a total of $80 \mathrm{lb}$ $(3457 \mathrm{lb} / \mathrm{acre})$ of berries from the field planting were harvested and the season ended after the first hard frost $\left(23^{\circ} \mathrm{F}\right)$ on 9 Oct. There was no yield difference among the five cultivars in 2009 (Table 3). The yield could have been higher, but the hard frost in early October killed immature fruit and flowers. In addition, there was high plant mortality rate in the planting year due to improper planting depth. Planting depth is critical for bare root raspberry planting. If they are planted too deep, the primocanes do not emerge and the plants may die (R. Walser, personal communication). Dead plants in the high tunnel were all replaced, but due to lack of planting material, they were not fully replaced in the field planting.

In this experiment, even though we could not directly compare the field yield with high tunnel yield due to a lack of true replication in the experimental design, the high tunnel yield was very different from the yield in the field. The average high tunnel yield was $4.27 \mathrm{lb} /$ plant, which is $380 \%$ of the average field yield of $1.12 \mathrm{lb} /$ plant in 2009 (Table 3). Comparing harvest seasons for the high tunnel and the field planting both years, use of the high tunnel plus supplemental propane heat at night extended the fruit harvest season for 4 weeks in the fall. Use of a high tunnel for planting clearly has the potential to increase primocanefruiting raspberry yield in cold climate areas such as northern Minnesota.

Fruit size. Average berry size in the high tunnel in 2009 (4.0 g) was smaller than in 2008 (4.4 g) [Table 3 (statistical analysis not shown)]. This could be partially due to the heavy crop in 2009 (Fig. 1).
Comparing the five cultivars in the high tunnel in 2009, 'Joan J' produced the largest fruit, followed by 'Autumn Britten' and 'Caroline' (Table 3). 'Polana' produced smaller fruit than those three, but the fruits were larger than those of 'Autumn Bliss'. For all cultivars, the fruit were larger in size at the beginning of the harvest period and decreased as the season continued. The heavy crop and the cool October weather likely contributed to fruit size decrease in late Sept. and Oct. 2009.

For the total $0.5 \mathrm{lb}$ of berries harvested in the field in 2008, the berry size was small, only about twothird of the berry size of the same cultivar in high tunnel. In 2009, the berry size ranking among cultivars in the field was generally the same order as in high tunnel and the average berry sizes of 'Autumn Bliss', 'Autumn Britten', and Joan J' from the field planting were comparable to the berry size in the high tunnel (Table 3 ). This could partly be due to the record warm September weather and the light crop in the field.

Plant growth AND SNOW COVER EFFECT. Raspberry plants in the high tunnel grew taller and had more branches than the field plants. On 6 Oct. 2008, average plant height for all five cultivars was 64 inches in the high tunnel vs. 25 inches in the field (Table 4). On 9 July 2009 , average height for plants in the high tunnel was 62 vs. 28 inches in the field. 'Polana' was the shortest among the five cultivars tested in the high tunnel (Table 4). Some plants grew over $7 \mathrm{ft}$ in the high tunnel in 2009. Pruning and 
Table 4. Primocane-fruiting raspberry plant height in the high tunnel $(\mathrm{HT})$ and in the field (Field) during 2008 and 2009 at Grand Rapids, MN (U.S. Department of Agriculture plant hardiness zone $3 \mathrm{~b}$ ).

\begin{tabular}{|c|c|c|c|c|}
\hline \multirow[b]{3}{*}{ Cultivar } & \multicolumn{4}{|c|}{ Plant ht (inches) ${ }^{\mathrm{z}}$} \\
\hline & HT & Field & HT & Field \\
\hline & \multicolumn{2}{|c|}{6 Oct. 2008} & \multicolumn{2}{|c|}{ 9 July 2009} \\
\hline Autumn Bliss & $69 \mathrm{a}^{\mathrm{y}}$ & $27 \mathrm{a}$ & $59 \mathrm{~cd}$ & $25 \mathrm{~b}$ \\
\hline Autumn Britten & $62 \mathrm{~b}$ & $26 \mathrm{a}$ & $64 \mathrm{~b}$ & $29 \mathrm{ab}$ \\
\hline Caroline & $67 \mathrm{ab}$ & $28 \mathrm{a}$ & $71 \mathrm{a}$ & $33 \mathrm{a}$ \\
\hline Joan J & $70 \mathrm{a}$ & $23 \mathrm{a}$ & $61 \mathrm{bc}$ & $27 \mathrm{ab}$ \\
\hline Polana & $51 \mathrm{c}$ & $22 \mathrm{a}$ & $57 \mathrm{~d}$ & $26 \mathrm{ab}$ \\
\hline Average & 64 & 25 & 62 & 28 \\
\hline
\end{tabular}

${ }^{2} 1$ inch $=2.54 \mathrm{~cm}$.

${ }^{y}$ Any two means within a column not followed by the same letter are significantly different at $P \leq 0.05$ with Fisher's protected least significant difference procedure.

Table 5. Raspberry primocane counts in the high tunnel after midwinter snow cover treatments in May 2009 at Grand Rapids, MN (U.S. Department of Agriculture plant hardiness zone $3 \mathrm{~b}$ ).

\begin{tabular}{lc}
\hline Cultivar $^{\mathrm{z}}$ & $\begin{array}{c}\text { Primocanes } \\
\text { (no./linear ft) }\end{array}$ \\
\hline Autumn Bliss & $4.7 \mathrm{~cd}^{\mathrm{x}}$ \\
Autumn Britten & $4.2 \mathrm{~d}$ \\
Caroline & $12.9 \mathrm{a}$ \\
Joan J & $7.2 \mathrm{bc}$ \\
Polana & $8.9 \mathrm{~b}$
\end{tabular}

Snow cover

Snow $\quad 8.6 \mathrm{a}$

No snow

$6.5 \mathrm{~b}$

${ }^{\mathrm{z}}$ Cultivar and snow cover were two separate main factors. The snow $\times$ cultivar interaction was not significant.

${ }^{\mathrm{y}} 1$ primocane $/ \mathrm{ft}=3.2808$ primocanes $/ \mathrm{m}$.

${ }^{\mathrm{x}}$ Any two means within a column not followed by the same letter are significantly different at $P \leq 0.05$ with Fisher's protected least significant difference procedure.

tipping has been used to increase the yield or extend the fruiting season in mild climates for raspberry and blackberries (Oliveira et al., 1996, 1998, 2004; Thompson et al., 2009). Pruning and tipping was not attempted in this trial except for a few of the 'Caroline' plants that were reaching the high tunnel roof. Pruning and tipping practices should be tested in the future for early-midseason cultivars in USDA plant hardiness zone $3 \mathrm{~b}$ areas.

In May 2009, 'Caroline' produced more primocanes than any other cultivars tested in the high tunnel (Table 5). 'Autumn Britten' had the fewest number of primocanes among the five cultivars (Table 5). The higher number of primocanes and more branches (data not shown) of 'Caroline' could partially contribute to its higher yield than others in the high tunnel. Winter snow cover provided the plants with some protection from the cold and resulted in an increase in the number of primocanes compared with the uncovered treatment (Table 5). Snow cover in winter may also help in maintaining soil moisture, although more study is needed to support these observations.

Plant NUtrition AND PEST MANAGEMENT. Nutrient analyses of leaf tissue indicated that essential elements were generally within sufficient ranges (Bushway et al., 2008) both in the field and in the high tunnel (data not shown). No symptoms of nutrient disorders were observed. Lack of nutritional problems is not surprising given the high levels of soil nutrients and optimal $\mathrm{pH}$ at this site.

Pest and disease pressure were not great in the high tunnel and differed from the field planting. The problems in the high tunnel were similar to those that might occur in a greenhouse, which agrees with other reports on diseases and pests in a high tunnel (Demchak, 2009). Using drip irrigation, leaves and fruit remained dry contributing to no observed gray mold (Botrytis cinerea) in the high tunnel. Spider mites were the major pest in our high tunnel starting in Sept. 2008. We did not spray in 2008 because the temperature dropped in early October and the mite population decreased naturally. In May and July 2009, predator mites were released to manage spider mites in the high tunnel, and this kept the spider mites under control throughout the season of 2009. Spider mites were not observed in the field.
Raspberry sawflies occurred in both the high tunnel and field plantings in both testing years. These insects eat the young tender leaves, leaving numerous holes on the fully expanded leaves. The sawflies have one generation in northern Minnesota, and no chemical control was used in this trial.

\section{Conclusions}

From the results of this experiment, primocane-fruiting raspberries would produce well under high tunnel conditions at Grand Rapids, MN, or in regions with similar climatic conditions. Plants grew taller, branched more, and produced higher yields in the high tunnel than in the field. A hard frost may kill plants in both high tunnels and in the field. Therefore, to maximize the high tunnel crop, a heating device for frost protection is necessary in cold regions. High tunnels plus a frost protection heating device extended the fruit season for 4 weeks in the fall, which allowed most fruit to be harvested during that time. High tunnel primocane-fruiting raspberry production is feasible as a niche crop for cold regions, but growers need to select appropriate cultivars and become familiar with details of tunnel management.

\section{Literature cited}

Brown, J.R. 1998. Recommended chemical soil test procedures for the North Central Region. North Central Regional Res. Publ. No. 221 (revised). Missouri Agr. Expt. Sta. SB 1001. 20 Oct. 2010. <http:// extension.missouri.edu/explorepdf/ specialb/sbl001.pdf $>$.

Bushway, L., M. Pritts, and D. Handley. 2008. Raspberry and blackberry production guide for the Northeast, Midwest, and Eastern Canada. Natural Resource Agr. Eng. Serv. NRAES-35, Ithaca, NY.

Cathy, H.M. 1990. USDA plant hardiness zone map. U.S. National Arboretum, Agr. Res. Serv., U.S. Dept. Agr. Misc. Publ. No. 1475 .

Demchak, K. 2009. Small fruit production in high tunnels. HortTechnology 19:44-49.

Fassel, V.A. and R.N. Kniseley. 1974. Inductively coupled plasma optical emission spectroscopy. Anal. Chem. 46: 1110A-1120A.

Heidenreich, M.C., M.P. Pritts, M.J. Kelly, and K. Demchak. 2009. High 
tunnel raspberries and blackberries. Cornell Univ., Dept. Hort. Publ. No. 47. 30 May 2011. <http://www.fruit. cornell.edu/berry/production/pdfs / hightunnelsrasp2009.pdf>.

Horneck, D.A. and R.O. Miller. 1998. Determination of total nitrogen in plant tissue, p. 75-83. In: Y.P. Karla (ed.). Handbook of reference methods for plant analysis. CRC Press, Boca Raton, FL.

Munter, R.C. and R.A. Grande. 1981. Plant tissue and soil extract analysis by ICP-AES, p. 653-673. In: R.M. Barnes (ed.). Developments in atomic plasma spectrochemical analysis. Heydon and Son, Philadelphia.

National Weather Service. 2006. Weather data for Grand Rapids (FRS), MN. 2 June 2011. <http://www.weather.gov/ climate $/$ xmacis.php?wfo $=\mathrm{dlh}>$.

Oliveira, P.B., C.M. Oliveira, L. Lopes da Fonseca, and A.A. Monteiro. 1996. Offseason production of primocane-fruiting red raspberry in mild winter climate using summer-pruning and polyethylene tunnels. HortScience 31:805-807.

Oliveira, P.B., C.M. Oliveira, P.V. Machado, L. Lopes da Fonseca, and A.A Monteiro. 1998. Improving off-season production of primocane-fruiting red raspberry by altering summer-pruning intensity. HortScience 33:31-33.

Oliveira, P.B., C.M. Oliveira, and A.A Monteiro. 2004. Pruning date and cane density affect primocane development and yield of 'Autumn Bliss' red raspberry. HortScience 39:520-524.

Rosen, C.J. and R. Eliason. 2005. Nutrient management for commercial fruit and vegetable crops in Minnesota. AGBU-05886. 3 June 2011. <http:// www.extension.umn.edu/distribution/ cropsystems/components/5886_full.pdf>.

Thompson, E., B.C. Strik, C.E. Finn, Y. Zhao, and J.R. Clark. 2009. High tunnel versus open field: Management of primocane-fruiting blackberry using pruning and tipping to increase yield and extend the fruit season. HortScience 44:15811587.

Wells, O.S. and J.B. Loy. 1993. Rowcovers and high tunnels enhance crop production in the northeastern United States. HortTechnology 3:92-95.

Wildung, D., S. Yao, and P. Johnson. 2007. Tomato spacing and pruning in the high tunnels, Upper Midwest Regional Fruit and Vegetable Growers 2007 Conf. Proc. P. 75-88.

U.S. Department of Agriculture. 2009a. 2007 Census of agriculture-Minnesota, state and county data. U.S. Dept. Agr. Publ. AC-07-A-23. 3 June 2011. <http:// www.agcensus.usda.gov/Publications/ 2007/Full_Report/Volume_1,_Chapter_ 2_County_Level/Minnesota/mnvl.pdf>.

U.S. Department of Agriculture. 2009b. Web soil survey. 20 Oct. 2010 . <http:// websoilsurvey.nrcs.usda.gov/app/ WebSoilSurvey.aspx $>$. 